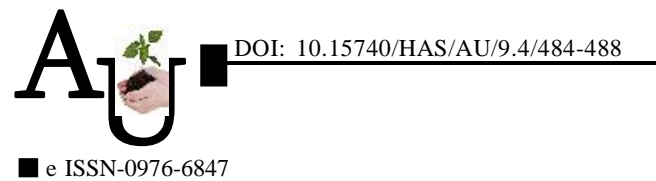

Research Article

\title{
Adoption of recommended soil and water conservation practices among the beneficiaries of Sujala Watershed Project in Northern Karnataka
}

\section{MITHUN P. KUDACHI, A. BHEEMAPPA, SHREESHAIL RUDRAPUR AND ANIL BIRADAR}

Article Chronicle:
Received :
28.07.2014;
Revised :
29.08.2014;
Accepted :
13.09.2014

KeY WoRdS :

Beneficiaries, Adoption, Soil, Water conservation practices, Sujala Watershed Project
SUMMARY : The study conducted during 2012-2013 in Haveri and Dharwad districts of Karnataka state where in Sujala watershed project was implemented during 2001 to 2007. The distribution of beneficiaries and nonbeneficiaries in adoption of recommended soil and water conservation practices shows that highest per cent of beneficiaries $(86.25 \%)$ as compared to non-beneficiaries $(57.50 \%)$ adopted shrub check. More number of beneficiaries adopted water ways $(65.00 \%)$, boulder bund $(62.50 \%)$, dugout or water recharge pit $(58.75 \%)$ and vegetative bunds $(52.50 \%)$ as compared to non-beneficiaries $(23.75 \%, 43.75 \%, 27.50 \%$ and $26.25 \%$, respectively). Around one-third of beneficiaries adopted sunken ponds (38.75\%) and farm pond (30.00\%) as compared to nonbeneficiaries $(13.75 \%$ and $16.25 \%$, respectively). Adoption of contour bund, rubble check, contour strip and staggered contour trench was noticed with very less per cent of beneficiaries $(12.50 \%, 8.75 \%, 6.25 \%$ and $6.25 \%$, respectively). But none of the non-beneficiaries adopted contour bund, contour strip and staggered contour trench. The overall distribution reveals that, high per cent of beneficiaries were noticed in high and medium adoption category $(43.75 \%$ and $40.00 \%$, respectively) as compared to non-beneficiaries (20.00\% and $27.50 \%$, respectively). Low adoption category was observed with more number of non-beneficiaries (52.50\%) as compared to beneficiaries $(16.25 \%)$. The extent of adoption amongst beneficiaries was positively correlated with land holding, extension participation, annual family income, awareness of soil erosion problems and accessibility to farm implements and the age was noticed to be negatively correlated. And amongst non-beneficiaries only annual family income was positively correlated with adoption of soil and water conservation practices Whereas, the education, farming system, family type, perception of usefulness of practices, achievement motivation and risk orientation were not related with the adoption of soil and water conservation practices among both beneficiaries and non-beneficiaries.

How to cite this article : Kudachi, Mithun P., Bheemappa, A., Rudrapur, Shreeshail and Biradar, Anil (2014). Adoption of recommended soil and water conservation practices among the beneficiaries of Sujala Watershed Project in Northern Karnataka. Agric. Update, 9(4): 484-488.

\author{
Author for correspondence :

\section{SHREESHAIL} \\ RUDRAPUR \\ Department of \\ Agricultural Economics, \\ College of Agriculture, \\ University of Agricultural \\ Sciences, DHARWAD \\ (KARNATAKA) INDIA \\ Email: shree4476@ \\ gmail.com
}

See end of the article for

authors' affiliations 